Conference to be held this year-are geared to the increasingly commercial aspect of the commission's activities. The Directorates for England, Scotland and Wales have been abolished, so that the various conservancies come under the direct control of a reconstructed headquarters. There are now three fulltime commissioners for administration and finance, for forest and estate management and for harvesting and marketing respectively. To act as intermediaries between the commissioners and the work which is going on in Scotland and Wales, senior officers for each of these countries have been appointed. Thus, the report says, co-ordination of policy is made easier, and the business of administration is simplified.

Although the primary concern of the commission is to produce timber to help meet the increasing demands of industry, there is growing recognition of the part forests can play in improving the landscape and in providing facilities for leisure and recreation. Car parks, picnic sites and nature trails are being provided to deal with increasing demand for public access. An officer with particular responsibility for wildlife was appointed in 1964, and the commission is taking advice from a landscape consultant.

The apparent consumption of forest products in the United Kingdom increased from 1,265 million cubic feet in 1961 to 1,461 million in 1965 . The production of sawn softwood has increased although sawn hardwood production has declined-there is a limited availability of high-quality home-grown hardwood logs and strong competition from abroad. The closure of uneconomic coal mines and increasing mechanization. in the more profitable ones have resulted in reduced consumption of mining timbers, and home production has decreased. The production of pulpwood has increased rapidly from 10.5 million cubic feet in 1960 to 17.5 million in 1965 . Imports of foreign pulpwood in 1965 were lower by 3 million cubic feet than 5 years previously.

The research and development activities of the commission have also been increasing; expenditure was $£ 554,000$ in 1965 , whereas it was $£ 363,000$ in 1960 . This represents approximately 3 per cent of the Forestry Commission's total payments. Under the new organization, the director of research is responsible to the commissioner for forest and estate management, and a management services division has been set up, under the commissioner for administration and finance, to cover planning and economics, work study and organization and methods.

The planning and economics branch has been making field surveys and inventories for the forest and conservancy working plans which are prepared by district officers and conservators. These working plans are a means of translating the commission's policy into local management terms. The work study branch is composed of seven regional teams and one experimental team, which conduct most of the development work and trials of machinery within the commission. Chemical weeding, brushing and draining are also being studied intensively.

Among the other research sections, an interesting development in forest pathology has been the development of a method for using the fungus Peniophora gigantea to control another fungus, Fomes annosus, by colonizing stumps more quickly and making them unsuitable for the root rotting pathogen. In silvi- culture, work has been developing on the effects of wind on trees. A technique using winches has been developed for estimating the resistance of stems to throw, and models have been constructed for study in wind tunnels. Aerodynamic studies of actual crops are now in progress.

\section{Tropical Products}

THe first model of a three and a half ton still for extract ing essential oils is now undergoing trials at the Tropical Products Institute's industrial technology department at Culham. The still, which costs $£ 3,850$, will be shipped to Dominica in the autumn where it will be used by the institute's staff to improve the quality of bay oil used to make bay rum. Fnquiries about the still have already been received from Grenada, St Vincent, Guyana, the Seychelles and Thailand, for use with flavouring oils such as cinnamon and nutmeg, the perfumery oil patchouli and for general exploration. Essential oils are like wine in that the flavour varies with the soil and weather conditions in each area.

Until now, countries wanting to develop the production of essential oils have had to construct their own test stills to produce samples. As these were often of the converted oil-drum variety, the flavour or smell of the resulting essence differed from the one which would

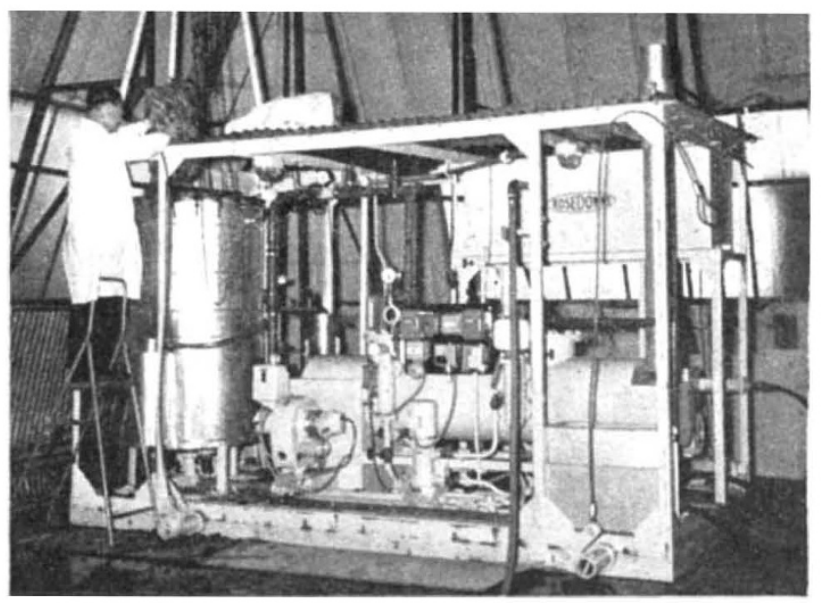

The still undergoing trials at Culham (Crown copyright).

be obtained from a proper still built for larger scale production. Thus there were often marketing difficulties because of the variation in the quality of the oils.

In July 1967, Dr G. Ames of the TPI produced the idea of a still which can be transported to areas of possible production and produce oils of consistent quality. Specifications for the still were developed by the institute and converted into hardware by Rose, Downs and Thompson of Hull. Any form of plant material can be placed in the stainless steel vessel, and the oils are removed by steam. After condensation, the distillate passes through two separators, the first for the removal of oils lighter than water, the second for the heavier variety. The still is run on diesel fuel, so that water is the only local requirement for its use. It can be carried by lorry to the production site, a distinct advantage when the yield from the process is between 2 and 5 per cent by weight. 